\title{
Human Health Risk Associated with Multiple Pathway Exposure to Arsenic in Contaminated Wetlands Cultivating Invasive Fish
}

\author{
Singh Atul K** and Srivastava Sharad C. \\ National Bureau of Fish Genetic Resources, Canal Ring Road, Dilkusha, Lucknow 226002 (Uttar Pradesh) India \\ *Corresponding Author
}

Received: $2^{\text {nd }}$ April, 2020

Accepted: $30^{\text {th }}$ April, 2020

Published online: $7^{\text {th }}$ May, 2020

https://doi.org/10.33745/ijzi.2020.v06i01.012

\begin{abstract}
The fish, water and sediment samples were examined for the presence of arsenic from six lakes in Ballia (Surha, Dah, Maniyar) and in Unnao (Nawabganj, Ajgaine and Asiwan) districts of Uttar Pradesh commonly producing water chestnut Trapa bispinosa locally known "singhara". Spraying of herbicides especially monosodium methanearsonate (MSMA) is very common in these water bodies.The estimated Arsenic (As) concentration in lake water ranged from $43.89 \pm 6.54 \mu \mathrm{g} / \mathrm{l}$ to $31.39 \pm 3.12 \mu \mathrm{g} / \mathrm{l}$ in Ballia and $22.21 \pm 4.4 \mu \mathrm{g} / \mathrm{l}$ to $10.78 \pm 2.32 \mu \mathrm{g} / \mathrm{l}$ in Unnao district at different sampling sites. The calculated total exposure of As level for adult was observed from 0.0042 $\mu \mathrm{g} / \mathrm{kg}$ body weight per day, while in children the exposure level was $0.0092 \mu \mathrm{g} / \mathrm{kg}$ body weight/day. Muscular concentration of As in Clarias gariepinus, Oreochromis niloticus and Cyprinus carpio captured from district Ballia was found higher $(0.017 \pm 0.009$ to $5.46 \pm 1.95 \mu \mathrm{g} / \mathrm{kg})$ than the concentration found in Unnao $(0.002 \pm 0.001$ to $1.75 \pm 0.39$ $\mu \mathrm{g} / \mathrm{kg}$ ). The combined hazard index (HI) value for As was 3.6 for Ballia and 1.8 for Unnao through different exposure routes. Human health risk assessment for As contaminants from different routes was calculated as per the processes and the probability of occurrence and the probable magnitude of adverse health effects over a specified time period. Food safety issue concerning human health has been addressed in this paper keeping in view of As bioaccumulation in hardy invasive fish species available particularly in Arsenic prone areas.
\end{abstract}

Keywords: Fish, Trapa bispinosa, Methanearsonate, Arsenic, Hazard index, Risk assessment

Citation: Singh Atul K.* and Srivastava Sharad C.: Human health risk associated with multiple pathway exposure to arsenic in contaminated wetlands cultivating invasive fish. Intern. J. Zool. Invest. 6 (1): 148-161, 2020.

https://doi.org/10.33745/ijzi.2020.v06i01.012

\section{Introduction}

Over the past two decades, occurrence of high concentrations of arsenic in water has been recognized as a major public-health concern in several parts of the world (Liu, 2010).
There are few reviews published covering the arsenic-contamination scenario around the world (Smedley and Kinniburgh, 2002; Mandal and Suzuki, 2002). With the discovery 
of newer sites in the recent past, the arseniccontamination scenario especially in Asian countries has changed considerably. Before 2000, there were only few major incidents of arsenic contamination in aquatic bodies reported from Bangladesh, India and China. Arsenic contamination in groundwater from the Padma-Meghna plain in Bangladesh was first reported in 1995 (Dhar et al., 1997). WHO reported that at least 140 million people of 50 countries are exposed to arsenic through arsenic-contaminated groundwater at levels above $10 \mu \mathrm{g} / \mathrm{L}$ and a majority of them live in India and Bangladesh (WHO, 2018). The areas and population of 50 arsenic-affected districts in Bangladesh was 118,849 $\mathrm{km}^{2}$ and 105 million respectively compared to the total area and population of the country-148, 393 $\mathrm{km}^{2}$ and 120 million respectively (Ahmad et al., 2018).

In India, the first case of arsenicosis was identified in 16 patients from one village of a district in West Bengal in July 1983 (Chakraborti et al., 2002). In arsenic-affected areas, a preliminary study showed the presence of elevated levels of inorganic arsenic in rice and vegetables (Chowdhury et al., 2001; Hassan et al., 2017). The source of arsenic is geogenic and is present in alluvial sediment of the Delta. The mechanism and cause of arsenic leaching from source has been suggested via theories of oxidation (Chowdhury et al., 1999; Chakraborti et al., 2001), reduction (Nickson et al., 2000), carbon reduction (Harvey et al., 2002), and microbial reduction (Islam et al., 2004). During June 2002, arsenic in groundwater was first reported in Semria Ojha Patti village of Sahapur police station in Bhojpur district of Bihar state in India (Chakraborti et al., 2003). In December 2003, arsenic contamination of water was found in Sahibganj district, Jharkhand state, which is situated in the Middle Ganges Plain (Anon, 2005). In the northeastern region of India for the first time, arsenic contamination was detected in water of the Upper Brahmaputra plain (Chakraborti et al., 2004). A preliminary study in 1976 on arsenic in dug-wells, hand-pumps, and springwater was reported from Chandigarh and different villages of Punjab, Haryana, and Himachal Pradesh in northern India (Datta et al., 1976). In Uttar Pradesh, arsenic contamination in many blocks and villages of Ballia, Ghazipur and Varanasi district has also been reported during 2004 and the issue is coming to the forefront.

The water chestnut herb is a host of traditional water crops besides fish, providing precious income for the community during the off-season. Fishermen use to raise different kinds of fish in local natural water bodies particularly lakes, which happens to be breeding sites of those fish as well. Some rice varieties such dooshavadlu, palagadda and kamalaksha are also among the other crops that are cultivated in the periphery of these lakes (Singh, 2011). Clarias gariepinus, Oreochromis niloticus and Cyprinus carpio are popular invasive exotic aquaculture species which are cultivated in several lakes and wetlands of Uttar Pradesh including the water bodies containing water chestnut as a crop (Singh, 2014). During the last few years, availability of tilapia, African catfish and common carp in commercial catches has increased (Singh and Lakra, 2011; Singh et al., 2014). Year-round availability and lower price of these fishes are probably indicators of their increased consumption (Singh et al., 2012, 2014). Fishes have been reported to have high tolerance and absorption of arsenic (Kar et al., 
2011). The amount of arsenic (As) found in fish is usually related to the concentration in the water and soil, especially the concentration of water soluble As, since water soluble As travels more easily from the aquatic environment (Sharma and Dwivedi, 2009). Since fishes are constantly exposed to pollutants in contaminated water, they could be used as excellent biological markers of arsenic (Canli and Atli, 2003).

Spraying of herbicides especially the monosodium methanearsonate (MSMA) is very common in paddy and water chestnut suffering from Straighthead disease including lakes particularly cultivating them (Gilmour and Wells, 1980). There are also reports revealing that straighthead is closely associated with the arsenic concentration in soil, and the severity of straighthead was found to increase significantly with the increase of arsenic concentration (Rahman et al., 2008; Datta and Sarkar, 2004). Since water bodies receiving arsenate contents are supposed to be contaminated with arsenic for which we do not have any scientific report. Consumption of As contaminated paddy, waterchestnut or even fishes have been reported to have risk potential for human (USEPA, 2019; Michael et al., 2011; Imar and Carlos, 2011; Ali et al., 2019). This paper reports the bioaccumulation of Arsenic in some fish species available in different lakes of the Ballia and Unnao districts of Uttar Pradesh which have recently been identified as arsenic prone areas (MoSPI, 2007; Sankararamakrishnan et al. 2015). We have attempted to correlate the bioaccumulation with the mobile phase episodes of arsenic contamination in Uttar Pradesh, demonstrated a spatially explicit ecological risk assessment that closely conforms to the general framework developed for the assessment of risks due to environmental toxicants (WHO, 2001; USEPA, 2016).

\section{Materials and Methods}

Study area:

The study area was natural lakes in the Nawabganj (S1) $\left(26^{\circ} 37^{\prime} 3.56 \mathrm{~N}, 80^{\circ} 39^{\prime} 13\right.$. $80 \mathrm{E})$, Ajgain (S2) $\left(26^{\circ} 36^{\prime} 59.39 \mathrm{~N}, 8^{\circ} 37^{\prime} 32\right.$. 32 E) and Asiwan (S3) $\left(26^{\circ} 37^{\prime} 40.08 \mathrm{~N}\right.$, $80^{\circ} 38^{\prime} 1$. 17E) of the Unnao district of Uttar Pradesh. The main source of water for these lakes is only rain water. It is a potential source for capture fisheries and forms the lifeline for rural economy and environment of the area. The study was also extended in famous SurhaTal (S4) $\left(25^{\circ} 51^{\prime} 7.75 \mathrm{~N}, 84^{\circ} 10^{\prime} 28.92 \mathrm{E}\right)$, Dah Tal (S5) $\left(25^{\circ} 51^{\prime} 01.22 \mathrm{~N}, 8^{\circ} 22^{\prime} 12.56 \mathrm{E}\right)$ and Maniyar Tal (S6) $\left(26^{\circ} 2^{\prime} 59.27 \mathrm{~N}\right.$, $84^{\circ} 3^{\prime} 10.45 \mathrm{E}$ ) located in the district of Ballia. It is an open natural lake in the floodplain of river Ganga. It is an important natural resource of fisheries in the Ballia district and eastern Uttar Pradesh.

\section{Sampling procedure and analysis:}

The fish, water and sediment samples were taken from the lakes of Unnao and Ballia following the Standard method (APHA, 2012) and quality monitoring was done as per the procedure of Central Pollution Control Board (CPCB, 2008; Singh et al., 2012). The invasive fish species used in this study were Clarias gariepinus, Oreochromis niloticus and Cyprinus carpio since they are hardy and tolerate harsh and pollution conditions. Each fish species was caught from the selected samplings lake sites using drag net, which were usually left over night in the Lake by local fishermen. Fishes (Clarias gariepinus, Oreochromis niloticus and Cyprinus carpio) were caught at 
S1 to S6 locations in the Unnao and Ballia districts.

\section{Muscle:}

The netted fish were recovered each morning in a sample box with some quantity of lake water and brought to the laboratory. The scales were removed using plastic knife. Approximately $2.0 \mathrm{~g}$ muscle of sample was weighed and placed in glass tubes. One gram of dried tissue (in three replicates) was then digested with standard method (APHA, 2012; Singh et al., 2014).

\section{Surface sediment:}

Surface sediment from each study sites was collected into pre-cleaned polythene bag using a stainless van-ven grab. Sediment samples were digested according Singh et al. (2014) and the volume was made $10 \mathrm{ml}$ with deionized water for further analysis.

\section{Water:}

A water sample was collected using plastic containers. $5 \mathrm{ml}$ of concentrated hydrochloric acid was added to $250 \mathrm{ml}$ of water sample and evaporated to $25 \mathrm{ml}$. The concentrate was transferred to a $50 \mathrm{ml}$ flask and diluted to mark with distilled water. Analyzing these variations and the collected data, we tried to find reliable relations between the variables and data, as well as helpful trends. Total As was detected in water samples, surface sediment sample and digested tissue samples by UNICAM-flame atomic absorption spectrophotometer (FAAS, Agilent) method through hydride generation technique (Jones and Laslett, 1994; APHA, 2012).

\section{Quality Control:}

Analysis of sample was done according to standard, reagent blank and sample replicate which were randomly inserted in the analysis process to assess contamination and precision. A sample of double distilled water divided into two, where one part was kept in the laboratory and other part was transported to the sample sites. The error from contamination due to transportation was 0.1020 to 0.1098 . Recovery studies of As metals determination were conducted to demonstrate the efficiency of the method. The recovery rates ranged from $83.3 \%$ to $92.2 \%$.

\section{Risk assessment:}

The hazard identification was done by monitoring of arsenic in surface water as well as fish muscle as described above. Quantification of exposure in relation to consumption of As was done by a multiple pathway exposure model (SEDISOIL) (Harma et al., 1999) using parameters in the exposure values (Table 1). The model was based on individual exposure routes: the surface water, sediment, and fish consumption. The following equations are incorporated into the model to calculate total exposure (Singh et al., 2014):

Ingestion of contaminated sediment $\left(\mathrm{mg} \mathrm{kg}^{-1}\right.$ day $\left.^{-1}\right)$
$=\frac{\mathrm{CS} \times \mathrm{IRs} \times \mathrm{EF} \times \mathrm{AF}}{\mathrm{BW}}$

where $\mathrm{CS}=$ concentration of the As in sediment (mg kg-1 dw), IRs = ingestion rate of sediment $(\mathrm{kg} / \mathrm{dw}$ exposure day), $\mathrm{AF}=$ absorption factor (unitless), and BW = body weight (kg).

Ingestion of surface water $(\mathrm{mg} / \mathrm{kg} /$ day)

$=\frac{\mathrm{CW} \times \mathrm{IRW} \times \mathrm{EF} \times \mathrm{AF}}{\mathrm{BW}}$ BW

where $\mathrm{CW}=$ concentration of the As in surface water $\left(\mathrm{mg} \mathrm{l}^{-1}\right)$ and $I R w=$ ingestion rate of surface water (per liter exposure day).

Ingestion of suspended material ( $\mathrm{mg} / \mathrm{kg} /$ day)

$=\mathrm{CM} \times \mathrm{CMW} \times \mathrm{IRW} \times \mathrm{EF} \times \mathrm{AF}$

where $\mathrm{CM}=$ concentration of AS contaminant in suspendedmatter $(\mathrm{mg} / \mathrm{kg} / \mathrm{dw})$ and $\mathrm{CMW}=$ suspended matter content of surface water $(\mathrm{kg} / \mathrm{l})$.

Dermal contact with contaminated sediment (mg/kg/day)

$=\underline{\mathrm{CS}} \times \mathrm{SAs} \times \mathrm{AD} \times \mathrm{ASs} \times \mathrm{Mf} \times \mathrm{EDs} \times \mathrm{EF} \times \mathrm{AF}$ 
where SAs = dermal surface area for sediment exposure $\left(\mathrm{m}^{2}\right)$, $\mathrm{AD}=$ dermal adherence rate for sediment $\left(\mathrm{mg}^{-1} \mathrm{~cm}^{2}\right)$, ASs = dermal absorption rate for sediment $(\mathrm{l} / \mathrm{h}), \mathrm{Mf}=$ matrix factor (unitless), and EDs = exposure duration from dermal exposure to sediment (h/day).

Dermal contact with contaminated surface water $(\mathrm{mg} / \mathrm{kg}$ $/$ day) $=\underline{\mathrm{CW}} \times \mathrm{SAw} \times \mathrm{ASw} \times \mathrm{EF} \times \mathrm{EDw} \times \mathrm{AF}$

$A S w=\frac{5000 \times\left(0.038+0.153 \times K_{o w}\right)}{5000+\left(0.038+0.153 \times K_{0 w}\right)} \times \frac{\exp (-0.016 \times M)}{1.5}$

where SAw = dermal surface area for exposure in surface water $\left(\mathrm{m}^{2}\right), \mathrm{ASw}=$ dermal absorption rate for exposure in surface water $\left[\left(\mathrm{mg} / \mathrm{m}^{2}\right) /(\mathrm{mg} / \mathrm{l}) / \mathrm{h}\right]$, EDw $=$ exposure duration from dermal exposure to surface water (h/day), $\mathrm{K}$ ow = octanol/water partition coefficient, and $\mathrm{M}=$ molecular weight (g mol-1).

Ingestion of fish $(\mathrm{mg} / \mathrm{kg} /$ day $)=\frac{\mathrm{CF} \times \mathrm{IRf} \times \mathrm{FI} \times \mathrm{AF}}{B W}$

where $\mathrm{CF}=$ concentration of the contaminant in fish $[\mathrm{mg} \mathrm{kg}-1$ fresh weight $(\mathrm{fw})], \mathrm{IRf}=$ ingestion rate of fish $(\mathrm{kg} / \mathrm{fw} /$ day $)$, and $\mathrm{FI}=$ fraction contaminated (unitless)

Calculated As exposure levels were compared with the tolerable daily intake (TDI). The TDI refers to the reference dose of a substance that can be taken in daily without identifiable risk at lifetime exposure. Additionally, the hazard index was calculated, which refers to the ratio of the calculated lifetime daily exposure divided by the reference dose (TDI). Daily exposure $(\mathrm{mg} / \mathrm{kg} /$ day) averaged over a lifetime (eg. 70 years) was calculated:

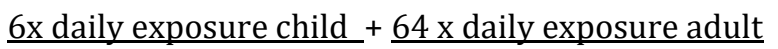
70 7

Carcinogenic risk:

The following equation was used for each exposure route (USEPA, 1989; Yongli et al., 2010):

Carcinogenic risk $=$ TDI $\times$ slope factor $\left[(\mathrm{mg} / \mathrm{kg} / \text { day })^{-1}\right]$

The reference dose (RfD) and carcinogenic potency slope factor (CPS) were used for health risks evaluation as provided by USEPA (USEPA, 2011). The cancer slope factors for ingested arsenic are 1.5. RfD is the reference dose (As= 0.003, $\mu \mathrm{g} \mathrm{g}^{-1}$ day $^{-1}$ ) (USEPA, 2011) that is likely to be without appreciable risk of deleterious effects during a lifetime (averaging time of 365 day $^{-1} \mathrm{yr}$ for $70 \mathrm{yr}$ ).

\section{Acceptable Risk Distribution:}

The lower end of the range of acceptable risk distribution was defined by a single constraint on the $95^{\text {th }}$ percentile of risk distribution that was equal or lower than $10^{-6}$ for carcinogens and was up to $10^{-4}$ in some circumstance. The health protection standard of lifetime risk for HI was 1 (USEPA, 2011).

\section{Statistical Analyses:}

All values from chemical analyses were presented as mean \pm SD. Data obtained from the experiment were subjected to one-way analysis of variance (ANOVA) test using the Statistical Package for the Social Sciences.

\section{Results}

Different levels of arsenic concentration have been observed in water, surface sediments and fish samples and the same are presented in Table 2. The results indicated that presence of As in fish tissues (muscle) was reasonably lower than it was present in surface sediments and water. Muscular concentration of As bioaccumulation in fishes in district Ballia was found higher $(0.017 \pm 0.009$-$5.46 \pm 1.95 \mu \mathrm{g} / \mathrm{kg}$ ) than it was present in Unnao $(0.002 \pm 0.001--1.75 \pm 0.39 \mu \mathrm{g} / \mathrm{kg})$. The level of muscular As was high (4.33 \pm 1.21 -$5.46 \pm 1.95 \mu \mathrm{g} / \mathrm{kg}$ ) in Oreochromis niloticus caught from lakes in Ballia. However, the As level in the same species was lower $(1.428 \pm 0.32--1.75 \pm 0.59 \mu \mathrm{g} / \mathrm{kg})$ in Unnao. The level of muscular As in Clarias gariepinus was much elevated and it was $2.04 \pm 1.16$ to 
Table 1: Parameters in used in the health risk estimations

\begin{tabular}{|c|c|c|c|c|}
\hline $\begin{array}{l}\text { Use of } \\
\text { symbol }\end{array}$ & Description & Unit & Value & References \\
\hline IRs & Ingestion rate of sediment & $\begin{array}{c}\begin{array}{c}\text { Kg dw exposure } \\
\text { day }^{-1}\end{array} \\
\text { (dw=dry weight) }\end{array}$ & $\begin{array}{c}10^{-3} \text { for child; } \\
0.35 \times 10^{-3} \text { for adult }\end{array}$ & Harma et al., 1999 \\
\hline IRf & Ingestion rate of fish & $\begin{array}{l}\text { kgfw day }{ }^{-1} \\
\text { (fw= flesh } \\
\text { weight) }\end{array}$ & $\begin{array}{l}0.015 \text { for child; } 0.055 \\
\text { for adult }\end{array}$ & Heijna and Hof, 1993 \\
\hline IRw & Ingestion rate of surface water & $\begin{array}{l}\text { Liter exposure } \\
\quad \text { day }^{-1}\end{array}$ & $\begin{array}{c}50 \times 10^{-3} \text { for child and } \\
\text { adult }\end{array}$ & Van Wijnen, 1982 \\
\hline $\mathrm{AF}$ & Absorption factor & Unit less & 1 for child and adult & Harma et al., 1999 \\
\hline ASs & Dermal absorption rate & $\mathrm{L} \mathrm{hr}^{-1}$ & $\begin{array}{l}0.01 \text { for child; } 0.005 \\
\text { for adult }\end{array}$ & Hawley, 1985 \\
\hline SAs & $\begin{array}{l}\text { Dermal surface area for sediment } \\
\text { exposure }\end{array}$ & $\mathrm{m}^{2}$ & $\begin{array}{l}0.17 \text { for child; } 0.28 \text { for } \\
\text { adult }\end{array}$ & Hawley, 1985 \\
\hline SAw & $\begin{array}{l}\text { Dermal surface area for exposure in } \\
\text { surface water }\end{array}$ & $\mathrm{m}^{2}$ & $\begin{array}{l}0.95 \text { for child } \\
1.80 \text { for adult }\end{array}$ & $\begin{array}{l}\text { Veerkamp and Ten } \\
\text { Berge , } 1990\end{array}$ \\
\hline $\mathrm{AD}$ & Dermal adherence rate for sediment & $\mathrm{mg}^{-1} \mathrm{~cm}^{2}$ & $\begin{array}{l}0.51 \text { for child } \\
3.75 \text { for adult }\end{array}$ & $\begin{array}{l}\text { Veerkamp and Ten } \\
\text { Berge , } 1990\end{array}$ \\
\hline Mf & Matrix factor & Unit less & $\begin{array}{l}0.15 \text { for child and } \\
\text { adult }\end{array}$ & Hawley,1985 \\
\hline EF & Exposure frequency & Days $^{-1} 365$ days & 30 for child and adult & Harma et al., 1999 \\
\hline BW & Body weight & $\mathrm{Kg}$ & $\begin{array}{l}15 \text { for child } \\
70 \text { for adult }\end{array}$ & $\begin{array}{l}\text { Veerkamp and Ten } \\
\text { Berge , } 1990\end{array}$ \\
\hline CMW & $\begin{array}{l}\text { Suspended matter content of surface } \\
\text { water }\end{array}$ & $\mathrm{kg} \mathrm{l}^{-1}$ & $\begin{array}{c}30 \times 10^{-6} \text { for child and } \\
\text { adult }\end{array}$ & Riza,1989 \\
\hline EDs & Exposure duration to sediment & hr day-1 & 8 for child and adult & Hawley, 1985 \\
\hline EDw & Exposure duration in surface water & hr day-1 & $\begin{array}{l}2 \text { for child } \\
1 \text { for adult }\end{array}$ & Harma et. al., 1999 \\
\hline $\mathrm{Fl}$ & Fraction contaminated & Unit less & 0.5 for child and adult & Fiore et al., 1989 \\
\hline Ow & Octanol/ water partition coefficient & $\mathrm{L} \mathrm{Kg}^{-1}$ & 1 for child and adult & Allison, 2005 \\
\hline SF & Carcinogenic potency slop, & $\mathrm{Mg}^{-1} \mathrm{~g}^{-1}$ day & 1.5 for child and adult & USEPA, 2011 \\
\hline
\end{tabular}


Table 2: Arsenic levels in fish muscle, surface sediment and lake water of Ballia district

\begin{tabular}{|c|c|c|c|c|}
\hline Locations & Species & Muscle $\left(\mu \mathrm{kgg}^{-1}\right)$ & Lake Surface Sediment $\left(\mu \mathrm{g} \mathrm{kg}^{-1}\right)$ & Lake Water $\left(\mu \mathrm{g} \mathrm{l}^{-1}\right)$ \\
\hline \multirow{3}{*}{ Surha lake } & Clarias gariepinus & $2.26 \pm 1.1$ & \multirow[t]{3}{*}{$2579.48 \pm 147.81$} & \multirow[t]{3}{*}{$31.39 \pm 3.12$} \\
\hline & Oreochromis niloticus & $5.46 \pm 1.95$ & & \\
\hline & Cyprinus carpio & $0.08 \pm 0.024$ & & \\
\hline \multirow{3}{*}{ Dah lake } & Clarias gariepinus & $2.27 \pm 1.13$ & \multirow[t]{3}{*}{$1813.98 \pm 306.54$} & \multirow[t]{3}{*}{$43.89 \pm 6.54$} \\
\hline & Oreochromis niloticus & $5.18 \pm 1.33$ & & \\
\hline & Cyprinus carpio & $0.08 \pm 0.062$ & & \\
\hline \multirow{3}{*}{ Maniyar lake } & Clarias gariepinus & $2.04 \pm 1.16$ & \multirow[t]{3}{*}{$1030.87 \pm 397.92$} & \multirow[t]{3}{*}{$31.89 \pm 8.58$} \\
\hline & Oreochromis niloticus & $4.3 \pm 1.21$ & & \\
\hline & Cyprinus carpio & $0.017 \pm 0.009$ & & \\
\hline \multirow[t]{3}{*}{ Nawabganj } & Clariasgariepinus & $0.322 \pm 0.12$ & \multirow[t]{3}{*}{$1026.04 \pm 192.52$} & \multirow[t]{3}{*}{$14.92 \pm 2.67$} \\
\hline & Oreochromis niloticus & $1.750 \pm 0.39$ & & \\
\hline & Cyprinus carpio & $0.004 \pm 0.001$ & & \\
\hline \multirow[t]{3}{*}{ Ajgaine } & Clariasgariepinus & $0.394 \pm 0.18$ & \multirow[t]{3}{*}{$997.68 \pm 101.21$} & \multirow[t]{3}{*}{$22.21 \pm 4.4$} \\
\hline & Oreochromis niloticus & $1.605 \pm 0.42$ & & \\
\hline & Cyprinus carpio & $0.003 \pm 0.001$ & & \\
\hline \multirow[t]{3}{*}{ Asiwan } & Clarias gariepinus & $0.385 \pm 0.22$ & \multirow[t]{3}{*}{$635.61 \pm 302.54$} & \multirow[t]{3}{*}{$10.78 \pm 2.32$} \\
\hline & Oreochromis niloticus & $1.428 \pm 0.32$ & & \\
\hline & Cyprinus carpio & $0.002 \pm 0.001$ & & \\
\hline
\end{tabular}

$2.27 \pm 1.13 \mu \mathrm{g} / \mathrm{kg}$ in Ballia district and $0.32 \pm 0.12$ to $0.394 \pm 0.18 \mu \mathrm{g} / \mathrm{kg}$ in Unnao as compared to its level in Cyprinus carpio (Table 2). The highest As concentration in sediment samples was found $2579.48 \pm 147.81 \mu \mathrm{g} / \mathrm{kg}$ in Suraha lake followed by, $1813.98 \pm 306.54$ $\mu \mathrm{g} / \mathrm{kg}$ in Dah lake and $1030.87 \pm 397.92 \mu \mathrm{g} / \mathrm{kg}$ in Maniyar lake in Ballia district. The highest value of arsenic $(2579.48 \pm 147.81 \mu \mathrm{g} / \mathrm{kg})$ in surface sediments was present in Surha Lake in Ballia as compared to other sampling sites. The As level in surface sediment at three sampling stations in Unnao district were $1026.04 \pm 192.52 \mu \mathrm{g} / \mathrm{kg}$ in Nawabganj, 997.68 \pm $101.21 \mu \mathrm{g} / \mathrm{kg}$ in Ajgain and 635.61 \pm 302.54 $\mu \mathrm{g} \mathrm{\textrm {kg } ^ { - 1 }}$ in Asiwan, respectively (Table 2). The water quality constituents of surface water, reference freshwater values of the lake and other global published values have been considered. In water samples the 
Table 3: Carcinogenic risk and average exposure levels ( $\left.\mu \mathrm{g} \mathrm{kg}^{-1} \mathrm{day}^{-1}\right)$ of Arsenic

\begin{tabular}{|l|c|c|c|c|}
\hline \multirow{2}{*}{ Exposure routes } & \multicolumn{2}{|c|}{ Ballia } & \multicolumn{2}{c|}{ Unnao } \\
\cline { 2 - 5 } & Adult & Child & Adult & Child \\
\hline Ingestion of sediment & $0.27 \times 10^{-3}$ & $3.61 \times 10^{-3}$ & $0.13 \times 10^{-3}$ & $1.77 \times 10^{-3}$ \\
\hline Ingestion of surface water & $0.87 \times 10^{-3}$ & $4.07 \times 10^{-3}$ & $0.34 \times 10^{-3}$ & $1.59 \times 10^{-3}$ \\
\hline Ingestion of suspended matter & $1.9 \times 10^{-6}$ & $4.3 \times 10^{-6}$ & $1.8 \times 10^{-6}$ & $3.8 \times 10^{-6}$ \\
\hline Dermal contact with sediment & $1.6 \times 10^{-4}$ & $3.7 \times 10^{-4}$ & $0.7 \times 10^{-4}$ & $1.7 \times 10^{-3}$ \\
\hline Dermal contact with surface water & $0.3 \times 10^{-3}$ & $1.2 \times 10^{-3}$ & $0.1 \times 10^{-3}$ & $0.2 \times 10^{-3}$ \\
\hline Ingestion of fish & $0.7 \times 10^{-6}$ & $0.3 \times 10^{-5}$ & $0.9 \times 10^{-6}$ & $0.7 \times 10^{-6}$ \\
\hline Total & 0.0016 & 0.0092 & 0.0006 & 0.005 \\
\hline Hazard indices (HI) & \multicolumn{2}{|c|}{3.6} & & 1.8 \\
\hline
\end{tabular}

concentration of the arsenic was $43.89 \pm 6.54$ $\mu \mathrm{g} / \mathrm{l}$ to $31.39 \pm 3.12 \mu \mathrm{g} / \mathrm{l}$ in Ballia and $22.21 \pm 4.4 \mu \mathrm{g} / \mathrm{l}$ to $10.78 \pm 2.32 \mu \mathrm{g} / \mathrm{l}$ in Unnao district. The concentrations of arsenic in samples from all sites were found above the detection limits $(0.002 \mu \mathrm{g} / \mathrm{l})$. The adsorption and accumulation of metals by suspended solids and the concentration of metals in surface sediments were found higher than in the water column below the surface sediments where it ranged from 635.61 \pm 302.54 to $1026.04 \pm 192.52 \mu \mathrm{g} / \mathrm{kg}$ in Unnao and $1030.87 \pm 397.92$ to $2579.48 \pm 147.81$ $\mu \mathrm{g} / \mathrm{kg}$ in Ballia (Table 2).

The calculated total exposure level for As was observed from $0.0016 \mu \mathrm{g} / \mathrm{kg}$ body weight /day for adult, $0.0092 \mu \mathrm{g} / \mathrm{kg}$ body weight/day for children in Ballia while it was 0.0006 $\mu \mathrm{g} / \mathrm{kg}$ body weight/day for adult; $0.005 \mu \mathrm{g} / \mathrm{kg}$ body weight /day for children in Unnao. The combined HI value for As was 3.6 and 1.8 in Ballia and Unnao, respectively. The HI value for metal was more than 1 under exposure routes (Table 3) which indicated that there might be some concern for adverse health effects. According to Equation 1 to 7, the carcinogenic risks caused by several single factors and the total risks caused by multiple factors have been presented in Table 3. Total exposure through different routes was maximum in children in Ballia district. Total exposure route value also indicated that it was observed maximally in children in both the districts. Arsenic maximally exposed through dermal contact with surface water and it exposed to children at higher level than adults. Arsenic also exposed through the ingestion of fish but exposure level through this route was maximum in adults $0.7 \times 10^{-6}$ in Ballia and $0.9 \times 10^{-6}$ in Unnao rather than children in both districts (Table 3). The risk due to ingestion of fish was, $0.7 \times 10^{-7}$ for children and $0.6 \times 10^{-7}$ for adults for Cyprinus carpio, $0.1 \times 10^{-4}$ for children and $0.1 \times 10^{-4}$ for adults for Oreochromis niloticus in Unnao 
district and $0.9 \times 10^{-6}$ for children and $0.8 \times 10^{-6}$ for adult for Clarias gariepinus. The calculated risk range through ingestion of fish was $0.2 \times 10^{-8}$ for children and $0.2 \times 10^{-8}$ for adults in case of Cyprinus carpio; $0.7 \times 10^{-5}$ for children and $0.5 \times 10^{-6}$ for adults, in case of Oreochromis niloticus and also for Clarias gariepinus in Ballia district. The calculated carcinogenic risk in Ballia was $6.24 \times 10^{-3}$ and $1.39 \times 10^{-3}$ in adults and children, respectively while it was $0.7 \times 10^{-3}$ for adults and $0.1 \times 10^{-3}$ for children in Unnao district. Comparing the carcinogenic values with guideline values of $10^{-6}-10^{-4}$ given in USEPA (2011), it was found that the risk through fish consumption from lakes of Ballia as well as in Unnao were although not alarming at present, might pose carcinogenic risk of As exposure in future.

\section{Discussion}

Analyses of 54 samples collected from 6 locations in the state of Uttar Pradesh revealed that values of arsenic varied in different locations. This study revealed that the surface water of the Ballia district showed higher degree of As contamination which is in conformity with the earlier report (Sankararamakrishnan et al., 2015). Analysis of arsenic in fish muscle showed species wise bio-concentration of the arsenic level. Sediment arsenic level was high particularly in Ballia district of Uttar Pradesh. Arsenic is toxic to both plant and animals and inorganic arsenicals are proven carcinogens in humans (Shrivastava et al., 2015). A wide range of arsenic toxicity has been determined that depends on arsenic speciation (Sharma and Sohn 2009; Shrivastava et al., 2015). Generally inorganic arsenic species are more toxic than organic forms to living organisms, including humans and other animals (Sharma and Sohn,
2009; Shrivastava et al., 2015). Results of samples analyzed in different lake showed a mean level of surface sediment arsenic of $1808.44 \mu \mathrm{g} / \mathrm{kg}$ in Ballia district and 886.44 $\mu \mathrm{g} / \mathrm{kg}$ in Unnao district, which could be due to use of arsenic herbicide. Maximum value of arsenic was found in Oreochromis niloticus which is currently understood as As hyperaccumulator species. An extensive survey of cooked Canadian foods elucidated an increase in total arsenic levels of cooked relative to uncooked food such as marine and freshwater fish. Similarly, total arsenic content of fresh sea bass fillets increased greatly upon microwave oven cooking of the fillets. The decrease in moisture content during cooking was suggested as the reason for increase in arsenic content (Sharma and Sohn, 2009; Kumarathilaka, 2019). There are very few reports on the wildlife poisoning by arsenic, however, Eisler (1988) reported it for the first time showing that catfish in the reservoir water contained 5 and $12 \mathrm{mg} \mathrm{kg}^{-1}$ of As which is relatively persistent in the aquatic environment (Bears et al., 2006). Tanner and Clayton (1990) reported elevated concentrations of arsenic in macrophytes where it was $193-1200 \mathrm{mg} \mathrm{kg}^{-1}$ dry weight and surfacial sediments $540-780 \mathrm{mg} / \mathrm{kg}$ dry weight in Lake Rotoroa, New Zealand. 24 years after an application of sodium arsenite herbicide; arsenic levels in a nearby reference lake (lake Rotokauri) was found $<20 \mathrm{mg} / \mathrm{kg}$ dry weight in macrophytes and 16.5--40 $\mathrm{mg} / \mathrm{kg}$ dry weight in surface sediments. Variation of arsenic, under the influence of water sand and fishes in lakes has been found and it differed between the lakes of the two districts (Ballia and Unnao). Arsenic in Ballia was greater than that in Unnao which correlates between various arsenic forms, 
supporting the possibility that arsenic partition in suspended particulates in lakes was driven mainly by biotic factor (Sankar et al., 2014). Arsenic mobility is greatly influenced by the concentration and nature of adsorbent surfaces and the adsorption process itself which is affected by many factors including but not limited to $\mathrm{pH}$. Under environmentally relevant conditions, dissolved organic matter tends to compete with dissolved arsenic species for active sites. As a result, the calculated risk that three persons per capita (1000 persons) would be in danger of skin diseases in the Ballia district and one person would be in skin diseases in the Unnao district has been reported (Tripathi, 2008).

Risk assessment for As contaminants was calculated as per the processes and the probability of occurrence of an event and the probable magnitude of adverse health effects over a specified time period (Kolluru et al., 1996). Human health risk assessment was carried out in three stages: (1) hazard identification, (2) exposure assessment and (3) risk characterization (Yongli et al., 2011). Risk-specific doses have been derived from the slope factor or unit risk to estimate the dose associated with a specific risk level (USEPA, 2005). Carcinogenic risks have been estimated as the incremental probability of an individual developing cancer over a lifetime as a result of exposure to a potential carcinogen (Kar et al., 2011). If a site has multiple carcinogenic contaminants, cancer risks for each carcinogen and each exposure route are added (assuming additivity of effects) and compared with the accepted risk (Liu et al., 2010). Risk assessment is the process of obtaining quantitative or qualitative measures of risk levels (USEPA, 1998; Singh et al., 2012). Risk assessments have traditionally focused on quantifying the probability of negative consequences from one or a number of identified or unknown sources. Sample variance and standard deviations were high, possibly due to wide variations in the levels of As in lake water. The surface water of the region showed elevated levels of arsenic, which could be influenced by the arsenic mix herbicides. Health risks from long-term ingestion of arsenic concentrations was found in the range of $10-100 \mu \mathrm{g} \mathrm{l}^{-1}$, and this ecological study was the first step in suggesting that moderately elevated arsenic concentrations in fish muscles are associated with mortality from cerebrovascular diseases, diabetes mellitus and kidney diseases by consumption of the fish in As prone areas and the possibilities are supported by the earlier report of Jaymie et al. (2007) and Oguri et al. (2014). The potential health risks associated with consumption of arsenic-contaminated fish and also from other routes are reported for arsenicosis, skin cancer, and other arsenicrelated diagnoses concentrations (WHO, 2004; Krishna et al., 2009; Majumdar et al., 2009; Roychowdhury et al., 2003; Uchino et al., 2006). Other researchers have performed risk assessments similar to that reported in Bangladesh and other countries, reporting elevated cancer risks (Chowdhury, 2010; Chen et al., 2005).

The United States Environmental Protection Agency (USEPA), considering hyperpigmentation, keratosis and possible vascular complications (blackfoot disease) as the critical effects of As, accepted the value of $0.3 \mu \mathrm{g} / \mathrm{kg} / \mathrm{day}$ as the reference dose in the case of human chronic exposure (Lyon, 1987). 
There is sufficient evidence that arsenic compounds are skin and lung carcinogens in humans. In our findings the calculated risk values through the ingestion of fish was maximum in Unnao i.e. it was $0.9 \times 10^{-6}$ $\mu \mathrm{g} / \mathrm{kg} /$ day in adult and $0.7 \times 10^{-6} \mu \mathrm{g} / \mathrm{kg} /$ day in children and minimum in Ballia where it was $0.7 \times 10^{-6} \mu \mathrm{g} / \mathrm{kg} /$ day in adult and $0.3 \times 10^{-}$ $5 \mu \mathrm{g} / \mathrm{kg} /$ day in children but overall exposure through different routes was higher in Ballia. In both the districts (Ballia and Unnao) the calculated risk value was more than 0.3 $\mu \mathrm{g} / \mathrm{kg} /$ day as per reference dose reported by USEPA which can create carcinogenic risk in human beings.

Arsenic is released into the environment through natural processes such as weathering, and may circulate in natural ecosystems for long time. A well-recognized arsenic problem of water in Utter Pradesh was first reported in the late 1980s. Comparatively higher concentration of arsenic accumulation was observed in Oreochromis niloticusin this study; however lower concentrations of As accumulation has been reported by other workers (Bhupander and Mukherjee, 2011). The observed concentration of arsenic in muscle tissue of fishes from Ballia was higher than fishes from Unnao. The arsenic forms are more hazardous to humans than the organic ones, which are generally of low toxicity. In fact, several days after its ingestion it gets excreted unchanged from the human body. Both organic and inorganic forms of arsenic occur in food. It has been established that fish can accumulate sizeable quantities of arsenic from their environment (Kar et al., 2011). The daily intake of arsenic by humans reflects generally the quantities of Rfd in the diet. As a result, there is no safe level of arsenic intake from food and water. There is a linear dose- response relationship between arsenic intake and health hazards down to very low levels of intake. Arsenic causes serious skin lesions and various forms of cancer and it can cause deaths from a wide range of other serious diseases (Meharg, 2005). Symptoms may not appear for 2 to 10 years from the start of chronic exposure and they may also appear long after exposure ceases (Jarup, 2003). Therefore, it is important to generate information on the arsenic and efforts need to be made to minimize arsenic intake from all sources as soon as possible. The results of this study revealed that consuming fish from lakes of Uttar Pradesh, where As is present in water and sediment may not be harmful to consumers because observed values of arsenic were below the permissible limits issued by FAO/WHO.

\section{Conclusion}

Assessing the bio-concentration as well as the bio-magnification potential of arsenic in fish is an important issue for the environmental and human health risk containment. Accumulation of As among the fish Clarias gariepinus, Oreochromis niloticus and Cyprinus carpio reflected differences in their bioaccumulation capabilities and further translocation to fish muscle. Hazard index of As suggested that contamination in most of the fish species had potential for human health risk due to consumption of edible part of the fish. Thus, regular monitoring of As contamination in the fish species especially cultivated in contaminated water is necessary and consumption of such contaminated fish should be avoided in order to reduce the health risk.

\section{Acknowledgement}

Authors are thankful to the Uttar Pradesh Pollution Control Board, India for their help in 
the analysis of samples.

\section{References}

Ahmad SK, Khan MH and Haque M. (2018) Arsenic contamination in groundwater in Bangladesh: implications and challenges for healthcare policy Risk Manag. Health Policy. 11: 251-261. doi: 10.2147/RMHP.S153188

Allison JD. (2005) EPA/600/R-05/074. July 2005 http://www.epa.gov/athens/publications/reports/ Ambrose600R05074PartitionCoefficients.pdf.

APHA. (2012) Standard methods for the examination of water and wastewater. Eds. Rice E W, Baird R B, Eaton $\mathrm{AD}$ and Clesceri LS., $22^{\text {nd }}$ edition, American Water Works Association American Public Health Association.

Bears H, Richards JG and Schulte PM. (2006) Arsenic exposure alters hepatic arsenic species composition and stress-mediated gene expression in the common killifish (Fundulus heteroclitus). Aquat. Toxicol. 77: 257-266

Bhupander K and Mukherjee DP. (2011) Assessment of human health risk for arsenic, copper, nickel, mercury and zinc in fish collected from tropical wetland in India. Adv. Life Sci. Technol. 2: 13-24

Canli M and Atli G. (2003) The relationships between heavy metal $(\mathrm{Cd}, \mathrm{Cr}, \mathrm{Cu}, \mathrm{Fe}, \mathrm{Pb}, \mathrm{Zn})$ levels and the size of six Mediterranean fish species. Environ. Pollut. 121: 129-136.

Chakraborti D, Basu GK, Biswas BK, Chowdhury UK, Rahman MM and Paul K. (2001) Characterization of arsenic bearing sediments in Gangetic Delta of West Bengal-India. In: Arsenic exposure and health effects. Eds. Chappell WR, Abernathy CO and Calderon RL. Elsevier Science, New York, p. 27-52.

Chakraborti D, Sengupta MK, Rahman MM, Ahamed S, Chowdhury UK and. Hossain MA. (2004) Groundwater arsenic contamination and its health effects in the Ganga-Meghna-Brahmaputra plain. J. Environ. Monit. 6: 74-83.

Chakraborti D, Rahman MM, Paul K, Chowdhury UK, Sengupta MK, Lodh D, Chanda CR, Saha KC and Mukherjee SC. (2002) Arsenic calamity in the Indian subcontinent. What lessons have been learned? Talanta 58: 3-22.

Chakraborti D, Mukherjee SC, Pati S, Sengupta MK, Rahman MM and Chowdhury UK. (2003) Arsenic groundwater contamination in Middle Ganga Plain, Bihar, India: A future danger. Environ. Hlth. Prospect 111: 1194-1201.
Chen CJ, Hsu LI, Wang CH, Shih WL, Hsu Y.H and Tseng MP. (2005) Biomarkers of exposure, effect, and susceptibility of arsenic-induced health hazards in Taiwan. Toxicol. Applied Pharmacol. 206: 198-206.

Chowdhury NT. (2010) Water management in Bangladesh: an analytical review. Water Pollution 12: $32-51$

Chowdhury TR, Basu GK, Mandal BK, Biswas BK, Samanta G and Chowdhury UK. (1999) Arsenic poisoning in the Ganges Delta. Nature 401: 545-546.

Chowdhury UK, Rahman MM, Mandal BK, Paul K, Lodh D and Biswas BK. (2001) Groundwater arsenic contamination and sufferings in West Bengal, India and Bangladesh. Environ. Sci. 8: 393-415.

CPCB. (2008) Guidelines for water quality monitoring, by Central pollution Control Board. https://www.indiawaterportal.org/articles/guideli nes-water-quality-management-and-monitoringcentral-pollution-control-board-2008.

Datta DV and Kaul MK. (1976) Arsenic contents of drinking water in villages in northern India: A concept of arsenicosis. J. Assoc. Physic. 4: 599-604.

Datta R and Sarkar D. (2004) Arsenic geochemistry in three soils contaminated with sodium arsenite pesticide: An incubation study. Environ. Eng. Geosci. 11: 85-95.

Dhar RK, Biswas BK, Samanta G, Mandal BK, Chakraborti D and Roy S. (1997) Groundwater arsenic calamity in Bangladesh. Curr. Sci. 73: 48-59.

Eisler R. (1988) Lead hazards to fish, wildlife, and invertebrates: A synoptic review. U.S. Fish Wildlife Service Biol. Rep. 85: 1-14.

Fiore BJ. Anderson HA, Hanrahan LP, Olson LJ and Sonzogni WL. (1989) Sport fish consumption and body burden levels of chlorinated hydrocarbons. A study of Wisconsin anglers. Arch. Environ. Hlth. 44: 82-88.

Gilmour JT and Wells BR. (1980) Residual effects of MSMA on sterility in rice cultivars. Agron.omy J. 72: 1066-1067.

Harma JA, Jean-Paul R, Edwin JCM, Jurian AH and Jos CSK. (1999) Human health risk assessment in relation to environmental pollution of two artificial fresh water lake in the Netherlands. Environ. Hlth. Prosp. 107: 27-35.

Harvey CF, Swartz CH, Badruzzaman ABM, Keon-Blute $\mathrm{N}, \mathrm{Yu}$ W, Ashraf AM, Jenny J, Roger B, Volker N, Daniel B, Peter MO, Asfaque KN, Islam S, Hemond HF and Feroz AM. (2002) Arsenic mobility and groundwater extraction in Bangladesh. Science 298: 1602-1606. 
Hassan FI, Niaz K, Khan F, Maqbool F and Abdollahi M. (2017) The relation between rice consumption,

arsenic contamination, and prevalence of diabetes in South Asia EXCLI J. 16: 1132-1143. doi: 10.17179/excli2017-222.

Hawley JK. (1985) Assessment of health risk from exposure to contaminated soil. Risk Analysis 5: 289-302.

Hazrat Ali H, Khan E and Ilahi I. (2019) Environmental chemistry and ecotoxicology of hazardous heavy metals: Environmental persistence, toxicity, and bioaccumulation, J. Chem. Article ID 6730305. https://doi.org/10.1155/2019/6730305.

Heijna ME and Hof M. (1993) Harmonization of model parameters. Rpt no 679102022 .Bilthoven, The Netherlands: National Institute of Public Health and the Environment.

Imar MR and Carlos JRS. (2011) Metal levels in fish captured in Puerto Rico and estimation of risk from fish consumption. Arch. Environ. Contamin. Toxicol. 60: 132-144.

Islam FS, Gault AG, Boothman C, Polya DA, Charnock JM and Chatterjee D. (2004) Role of metal-reducing bacteria in arsenic release from Bengal delta sediments. Nature 430: 68-71.

Jarup L. (2003) Impact of environmental pollution on health: Balancing risk. British Medical Bull. 68: 167-182.

Jaymie RM, Robert L., Lorraine LC and Jerome ON. (2007) Arsenic in drinking water and cerebrovascular disease, diabetes mellitus, and kidney disease in Michigan: A standardized mortality ratio analysis. Environ. Hlth. 6: 4.

Jones BR and Laslett RE. (1994) Methods for analysis of trace metals in marine and other samples. Aquatic Environment Protection: Analytical Methods. MAFF Directorate Fisheries Research, Lowestoft, 11: 29.

Kar S, Maity JP, Jean JS, Liu CC, Liu CW, Bundschuh J and Lu HY. (2011) Health risks for human intake of aquacultural fish: Arsenic bioaccumulation and contamination. J. Environmental Sci. Hlth. A 46: 1266-1273.

Kolluru RV, Bartell S, Pitblado RE and Stricoff S. (1996) Risk assessment and management handbook, N. Y. McGraw-Hill.

Krishna AK, Satyanarayanan M and Govil PK. (2009) Assessment of heavy metal pollution in water using multivariate statistical techniques in an industrial area: A case study from Patancheru, Medak District, Andhra Pradesh, India. J. Hazard. Mat. 167: 366-373.
Kumarathilaka P, Seneweera S, Yong SO, Meharg A and Bundschuh E. (2019) Arsenic in cooked rice foods: Assessing health risks and mitigation options. Environ. Intern. 127: 584-591.

Liu C, Luo C, Gao Y, Li F, Lin L, Wu C and Li X. (2010) Arsenic contamination and potential health risk implications at an abandoned tungsten mine, Southern China. Environ. Pollut. 158: 820-826.

Lyon FR. (1987) Overall evaluations of carcinogenicity: An updating of IARC Monographs Volumes 1 to 42., International Agency for Research on Cancer, IARC Monographs on the Evaluation of Carcinogenic Risk to Humans, Supplement 7: 100-106.

Majumdar KK, Mazumder GDN, Ghose N, Ghose A and Lahiri S. (2009) Systemic manifestations in chronic arsenic toxicity in absence of skin lesions in West Bengal. Indian. J. Med. Res. 129: 75-82.

Mandal BK and Suzuki KT. (2002) Arsenic around the world: A review. Talanta 58: 201-35.

Meharg AA. (2005) Venomous earth: New York, NY, Macmillan, 192.

Michael AM, Matthew RM and Michael FEW. (2011) Elevated levels of metals and organic pollutants in fish and clams in the Cape Fear River watershed. Arch. Environ. Contam.Toxicol. 61: 461-471.

MoSPI (2007). http://www.indiawaterportal.org/sites/ indiawaterportal.org/files/MoSPI_Compendium_of_ Environment_Statistics_India_2007.pdf

$\mathrm{Ng}$ JC. (2005) Environmental contamination of arsenic and its toxicological impact on humans. Environ. Chem. 2:146-160.

Nickson R, McArthur JM, Ravenscroft P, Burgess WG and Ahmed KM. (2000) Mechanism of arsenic release to groundwater, Bangladesh and West Bengal. Appl. Geochem. 15: 403-413.

Niedzielski P and Siepak M. (2003) Analytical methods for determining arsenic, antimony and selenium in environmental samples Polish J. Environ. Studies 12: 653-667.

Oguri T, Yoshinaga J, Tao $\mathrm{H}$ and Nakazato T. (2014) Inorganic arsenic in the Japanese diet: Daily intake and source. Arch. Environ. Contam. Toxicol. 66: 100-112.

Rahman MA, Hasegawa H, Rahman MM, Miah MAM and Tasmin A. (2008) Straighthead disease of rice (Oryza sativa L.) induced by arsenic toxicity. Environ. Exp. Bot. 62: 54-59.

Riza (1989) The Possibility for surface water organism to survive [in Dutch). Rpt. no 89016a. Lelystad, The 
Netherlands: The Institute of Water Management and Waste Water Treatment.

Roychowdhury T, Tokunaga H and Ando M. (2003) Survey of arsenic and other arsenic in food composites and drinking water and estimation of dietary intake by the villagers from an arsenicaffected area of West Bengal, India. Sci. Total Environ. 308: 15-35.

Sankararamakrishnan N, Gupta A and Chauhan V S. (2015) Status of arsenic contamination along the Gangetic Plain of Ballia and Kanpur district, Uttar Pradesh, India and possible remedial measures. In: In: Safe and Sustainable Use of ArsenicContaminated Aquifers in the Gangetic Plain. (Eds.) Ramanathan A, Johnston S, Mukherjee A and Nath B. Springer. https://doi.org/10.1007/978-3-31916124-2_17.

Sharma D and Dwivedi S. (2009) Arsenic threat and its remediation through plants: A step for environmental clean up. Intern. Soc. Environ. Botanists 15. https://isebindia.com/09-12/09-101.html.

Sharma VK and Sohn M. (2009) Aquatic arsenic: Toxicity, speciation, transformations and remediation. Environ. Intern. 35:743-759.

Shiv Shankar, Uma Shanker U and Shikha (2014) Arsenic contamination of groundwater: A review of sources, prevalence, health risks and strategies for mitigation. Sci. World J. 2014: Article ID 304524. https://doi.org/10.1155/2014/304524.

Shrivastava A, Ghosh D, Desh A and Bose S. (2015) Arsenic contamination in soil and sediment in India: Sources, effects and remediation. Curr. Pollu. Rep. 1: 35-46.

Singh AK. (2014) Emerging alien species in Indian aquaculture: prospects and threats. J. Aquatic Biol. Fish. 2: 32-41.

Singh AK and Lakra WS. (2011) Risk and benefit assessment of alien fish species of the aquaculture and aquarium trade into India. Rev. Aquacult. 3: 3-18.

Singh AK, Srivastava SC, Ansari A, Kumar D and Singh R (2012) Environmental monitoring and health risk assessment of African catfish Clarias gariepinus (Burchell, 1822) cultured in rural ponds, India. Bull. Environ. Contam. and Toxicol. 89: 1142-1147.

Singh AK, Srivastava SC, Verma P, Ansari A and Verma A. (2014) Hazard assessment of metals in invasive fish species of the Yamuna River, India in relation to bioaccumulation factor and exposure concentration for human health implications. Environ. Monitor. Assess. 186: 3823-3836.
Singh SH. (2011) Water crop cultivation not profitable for fishermen. The Hindu, December 5, 2011.

Smedley Pl and Kinniburgh DG. (2002) A review of the source, behaviour and distribution of arsenic in natural waters. Appl. Geochem. 17: 517-68.

Tanner CC and Clayton JS. (1990) Persistence of arsenic 24 year after sodium arsenite herbicide application to lake Rotora, Hamilton, New Zeland. New Zeland J. Mar. Freshwater Res. 24 : 173-179.

Tripathi PK. (2008) District brochure of Ballia district, U.P. http://cgwb.gov.in/District_Profile/UP/Ballia. pdf

Uchino T, Roychowdhury T, Ando $\mathrm{M}$ and Tokunaga $\mathrm{H}$. (2006) Intake of arsenic from water, food composites and excretion through urine, hair from a studied population in West Bengal, India. Food Chem. Toxicol. 44: 455-61.

USEPA (1989) Risk assessment guidance for superfund, Vol. I, human health evaluation manual.. Part A (interim final), EPA/540/1-89/002. Washington, DC: Office of Emergency and Remedial Response, US Environmental Protection Agency.

USEPA (2005) Guideline for carcinogen risk assessment http://www.epa.gov/raf/publications/pdfs/CANCE R_GUIDELINES_FINAL_3-25-05.PDF

USEPA (2011) USEPA Regional Screening Level (RSL) Summary Table: November 2011. http://www. epa. gov/regshwmd/risk/human/Index.htm.

USEPA (2016) Guidelines for human health Risk Assessment. https://www.epa.gov/risk/human health -risk-assessment.

USEPA (2019) Fish and shellfish advisories and safe eating guidelines. Office of Science and Technology of Water, Washington. https://www.epa.gov/ choose- fish-and-shellfish-wisely/fish-and-shellfishadvisories-and-safe-eating-guidelines.

Veerkamp W and Ten Berge W. (1990) Hazard assessment of chemical contaminants in soil. ECETOC Technical Rpt 40. Brussels: European Chemical Industry Ecology and Toxicology Centre.

WHO (2001) Arsenic and arsenic compounds. Environmental Health Criteria 224, second ed. World Health Organization, Geneva.

WHO (2004) Environmental levels and human expsoure. In: Environmental Health Criteria 224: Arsenic and Arsenic Compounds. Geneva: WHO, 67167.

Yongli Li, Jingling L, Zhiguo $\mathrm{C}$. Chao L and Zhifeng Y. (2010) Spatial distribution and health risk of arsenic and polycyclic aromatic hydrocarbons (PAHs) in the water of the Luanhe River Basin, China. Environ. Monit. Assess. 163: 1-13. 